\title{
Language choice and language contact in print advertisements for Russian-speaking immigrants in Germany
}

\author{
Anna RITTER \\ University of Regensburg \\ Regensburg, Germany
}

\begin{abstract}
This study aims to analyze linguistic contact in a written language on a sample of advertisements for Russian-speaking immigrants in the German city of Nuremberg, where there is a well-developed infrastructure for Russian-speaking immigrants, including the availability of periodicals. The study has the following research questions: What functions do Russian and German, as well as other languages, perform in advertisements in periodicals for Russian-speaking immigrants? Is there a correlation between the subject matter of the ads and the language or languages used? What phenomena of language contact found in the spoken language of Russian-speaking immigrants are characteristic of advertisements? A corpus consisting of 443 advertisements, obtained through continuous sampling from periodicals, was collected for the study. The analysis revealed that Russian, German, English, Ukrainian, and Latin fulfil specific functions in the advertisements. It was found that, depending on the subject matter, advertisers choose a particular language or language combination for their ads. At the lexical and morphosyntactic levels were identified borrowings from German and English, entirely or partially grammatically integrated into Russian, and cases of code-switching between Russian and German. Thereby, the study highlights one aspect of the linguistic situation of the Russian-speaking community in Germany and may implicitly serve to assess the vitality of the Russian language in Germany.
\end{abstract}

Keywords: multilingualism, print advertising, Russian-speaking immigrants in Germany, codeswitching, borrowings

\section{For citation:}

Ritter, Anna. 2021. Language choice and language contact in print advertisements for Russianspeaking immigrants in Germany. Russian Journal of Linguistics 25 (4). 958-980. https://doi.org/10.22363/2687-0088-2021-25-4-958-980 


\title{
Выбор языка и языковой контакт \\ в печатных рекламных объявлениях \\ для русскоязычных иммигрантов в Германии
}

\author{
Анна РИТТЕР \\ Регенсбургский университет \\ Регенсбург, Германия
}

\begin{abstract}
Аннотация
Целью данного исследования является анализ выбора языка и языковых контактов в письменной речи на примере рекламных объявлений для русскоязычных иммигрантов. Данные были собраны в немецком городе Нюрнберг, где имеется хорошо развитая инфраструктура для русскоязычных иммигрантов, включающая в себя периодические печатные издания. В рамках исследования были поставлены следующие исследовательские вопросы: (1) какие функции выполняют русский и немецкий, а также другие языки в рекламных объявлениях в периодических печатных изданиях для русскоязычных иммигрантов; (2) существует ли связь между тематикой объявлений и используемым языком или языками; (3) какие феномены языкового контакта, встречающиеся в устной речи русскоязычных иммигрантов, характерны для рекламных объявлений. Материалом исследования послужил корпус, состоящий из 443 рекламных объявлений, извлеченных методом сплошной выборки из периодических печатных изданий. Анализ показал, что в объявлениях использовались русский, немецкий, английский, украинский языки и латынь, выполняющие определенные функции и, как правило, используемые для отдельных элементов текста. Также было установлено, что на выбор языка или языков объявления влияет их тематика. На лексическом и морфосинтаксическом уровнях были выявлены заимствования из немецкого и английского языков, которые полностью или частично грамматически интегрированы в русский язык, а также случаи переключения кодов между русским и немецким языками. Таким образом, исследование освещает один из аспектов языковой ситуации русскоязычного сообщества в Германии и может косвенно служить для оценки жизнеспособности русского языка в Германии.
\end{abstract}

Ключевые слова: многоязычие, печатная реклама, русскоязычные иммигранты в Германии, переключение кодов, заимствования

\section{Для цитирования:}

Ritter A. Language choice and language contact in print advertisements for Russian-speaking immigrants in Germany. Russian Journal of Linguistics. 2021. Vol. 25. № 4. P. 958-980. https://doi.org/10.22363/2687-0088-2021-25-4-958-980

\section{Russian-speaking immigrants in Germany}

The second half of the 1980s and the 1990s was marked by population outflows from the Soviet Union, and later its 15 successor states to different countries of the world, including Germany. This so-called 4th emigration wave (KharitonovaAkhvlediani 2011: 17-19) at the end of the 20th century was triggered by the processes of political transformation and subsequent collapse of the Soviet Union (Dietz \& Roll 2019: 101). Today, along with immigrants from Turkey, Poland, Romania, and the former Yugoslavia, Russian-speaking immigrants form one of the largest immigrant communities in Germany (Statistisches Bundesamt 2019). 
According to the German Federal Statistical Office for 2019, there are about 3.5 million people from the former Soviet Union, 2.7 million of whom have personal immigration experience (Statistisches Bundesamt 2019). These are mainly immigrants from Russia, Kazakhstan, Kyrgyzstan, and Ukraine. Most of them had either no or limited knowledge of German when they arrived in Germany, considering Russian as their first and often only language (Dietz \& Roll 2019: 109-110).

Russian-speaking immigrants are divided into three groups (KharitonovaAkhvlediani 2011: 20-25, Dietz \& Roll 2019: 103-108). The first and the most numerous group form ethnic (Russian) Germans. They are the descendants of Germans who migrated from various German regions to the Russian Empire in the eighteenth and nineteenth centuries. Before 1941, the German settlers lived in closed, religiously organized communities where they used only the German language, or rather German dialects, and were thus virtually isolated from the rest of society (Baur, Chlosta \& Roll 2019: 82-83). In the summer of 1941, after the German invasion of the Soviet Union began, the communities were abolished, and Russian Germans were deported to Siberia, from where they were able to resettle independently in the Soviet republics of Central Asia after the war. However, they were never allowed to return to the European part of the USSR and rebuild their autonomous republic (Worbs et al. 2013). Most of them lost their German dialects due to heavy assimilation pressure and switched to Russian (Baur, Chlosta \& Roll 2019: 88-91).

The second group of Russian-speaking immigrants consists of 235,000 people of Jewish origin who arrived in Germany between 1991 and 2015 from the former Soviet Union, including the Baltic States (Dietz \& Roll 2019: 106). Almost none of them spoke German upon arrival (Dietz \& Roll 2019: 106).

The third group of at least 417,000 people (Ritter 2018: 236) consists of Russian-speaking immigrants who moved to Germany for different reasons and with varying levels of the German language. This group is sometimes divided into the following subgroups: immigration due to studies, work, family reunification, or as refugees (Kharitonova-Akhvlediani 2011: 23-25, Dietz \& Roll 2019: 107-108).

The peak of the Russian-speaking immigration wave was at the beginning of the 1990s when 150,000-200,000 people came to Germany every year. Since 1996, the number of arrivals has been decreasing (Haug \& Sauer 2007: 20, Worbs et al. 2013: 32-33). Thus, the majority of immigrants have been living in Germany for some 25-30 years. This long period, the significant size of the community, and the relatively low level of German language skills (Kharitonova-Akhvlediani 2011: 41), at least in the first years after immigration, served as a precondition for the development of Russian-speaking infrastructure in Germany. The infrastructure includes, for example, grocery shops, travel agencies, transport companies, lawyers and doctors specializing in Russian-speaking clients and patients, beauty salons, cultural-educational centres, Russian nurseries, schools, as well as weekend schools offering a variety of Russian language courses, music lessons, and choreography classes. 
The Russian-speaking infrastructure also includes such media as print and electronic periodicals, satellite TV, and one Russian-speaking radio station in Berlin. Major print media include newspapers such as, for example, "Диалог" (Dialogue), "Кругозор" (Horizons), "Карьера" (Career), "Русская Германия" (Russian Germany), "Районка" (Rayonka), "ТВ-бульвар" (TV Boulevard), "Еврейская панорама" (Jewish Panorama), and journals "У нас в Баварии" (Here in Bavaria), "Neue Zeiten" (New Times), "Партнёp" (Partner), and "Катюша" (Katyusha). Many of these are distributed free of charge and are used primarily as advertising space.

The developed Russian-speaking infrastructure, directly and indirectly, serves to increase the vitality of the Russian language, which is the most widely spoken Slavic language in Germany (Achterberg 2005). Furthermore, advertisements in print media form part of the network of communication within the community, which, however, does not live in isolation from the rest of German society. Most Russian-speaking immigrants speak German to some extent, communicate in this language at least at work or in public institutions, use German-language media, and are thus bilingual (Dietz \& Roll 2019, Meng 2019). Earlier studies in contact linguistics show that the linguistic phenomena of borrowing, code-switching, and code-mixing, i. e. between German and Russian, are characteristic of the spoken language of Russian-speaking immigrants (Goldbach 2005, Pabst 2007, Pavlova 2019, Warditz 2019).

Based on this background information, the present study aims to answer the following questions: What functions do Russian, German, and other languages have in advertisements printed in the periodicals for Russian-speaking immigrants? Is there a connection between the subject matter of the advertisements and the language or languages used? What language contact phenomena, found in the spoken language of Russian-speaking immigrants, are characteristic of advertisements?

\section{Theoretical background}

\subsection{Multilingualism, code-switching and borrowings}

Linguistic contacts between people speaking different languages have existed since time immemorial. These contacts were the results of trade, war, colonization, migration, the spread of religions, or for other reasons (Stavans \& Hoffmann 2015: 12-19). However, the phenomenon of bilingualism and/or multilingualism only gained attention in the twentieth century. Weinreich (1967: 1) and Haugen (1956: 9) used the term 'bilingualism.' Weinreich (1967: 1) defines bilingualism as "the practice of alternately using two languages". Haugen (1956: 9) uses the term 'bilingualism' as a general term for all people who speak more than one language. Contemporary definitions of the terms 'bilingualism' and 'multilingualism' highlight different aspects of the phenomenon. On the one hand, they emphasize that multilingualism exists as a synonym for bilingualism. On the other, depending on the context, the term 'bilingualism' indeed means only two languages (Swann et al. 2004: 214-215). 
In the present study, the term 'multilingualism' is a synonym for the term 'bilingualism.' Thus, people are described as multilingual if they have learned more than one language during their lifetime. It does not matter whether the languages were acquired naturally in the family or learned at school classes and in language courses. Besides, in the context of immigration, the term 'life multilingualism' is used (Gogolin 1998: 76-77), since for many immigrants, multilingualism is an everyday practice of linguistic border-crossing and linguistic border existence (Gogolin 1998: 92-93).

In this everyday practice, the linguistic border existence manifests itself in the use of two or more languages in immigrants' speech and in the phenomena of codeswitching and borrowing. In this case, code refers to both languages and their varieties, e. g. dialects (Riehl 2009: 20).

During recent decades, interest in the phenomenon of code-switching has grown considerably, which is confirmed by numerous studies with all kinds of language combinations (Gardner-Chloros 2011: 9). However, despite the diversity of studies, or perhaps just because of this diversity, there is no consensus among scholars on the definition for this term (Muysken 2000: 4, Riehl 2009: 20, Matras 2011: 101). In the present study, the term 'code-switching' refers to speakers using more than one language or language variety in the same utterance (Velupillai 2012: 404).

In recent decades, there have been studies looking at different aspects of the phenomenon of code-switching in spoken language (Gardner-Chloros 2011, Stavans \& Hoffmann 2015 as examples). However, the phenomenon of codeswitching does not only apply to oral but also to written forms of communication, such as advertisements and posters (Gardner-Chloros 2011: 6, Sebba 2012: 1).

Along with code-switching in colloquial speech, the phenomenon of borrowing is widespread in the context of the use of two or more languages. The integration of borrowings into the host language can occur at different levels: phonological, morphological, semantic, and graphic (Gardner-Chloros 2011). Borrowings may be integrated morphologically and syntactically by adding endings and syntactic functions from the host language, such as in the expression 'du bikest' where the English word receives a German verb ending (Riehl 2009: 21-22), or they may acquire an additional morphological feature, such as the word 'le weekend' borrowed from English into French and given an article (Swann et al. 2004: 30). In other cases, borrowings are not phonetically integrated, such as the words 'Restaurant' and 'Pendant' borrowed from French into German (Riehl 2009: 22). In addition, borrowings may be widespread within a certain linguistic community when not only bilinguals but also monolinguals can understand them (Swann et al. 2004).

It is not always possible to accurately distinguish the phenomenon of codeswitching from the phenomenon of borrowing. Opinions on this issue differ in the scientific literature (Riehl 2009: 21). The present study supports the view that both phenomena - borrowing and code-switching - are on a so-called continuum (Matras 2011: 113). 


\subsection{Multilingualism in advertising texts}

Advertising in contexts such as television, radio, film, print, internet, and outdoor advertising is an integral part of everyday life for modern people. As for any complex and multi-dimensional phenomenon, there are many definitions to describe advertising. These definitions consider both the process of creating advertising products and their relationship to the target audience from different angles. From the perspective of economic theory, advertising is a tool that is used as part of the overall marketing mix to achieve specific marketing goals (Rogge 2000: 28). Advertising is a form of communication between people which is initiated, shaped and paid for by a specific advertiser and directed to recipients whose specific composition is indefinite (cf. Armstrong 2010, Arslanagic-Kalajdzic \& Zabkar 2016). Based on cultural theory, advertising, especially its linguistic component, is a mirror of the culture in which it emerges, e. g. American, German or Russian (cf. Roche 2001: 11-13). Finally, from the point of view of the cognitive process, advertising, or more precisely the creation of advertising products, is inextricably linked to creativity (McStay 2013).

Although the specific composition of the addressees of advertising is indefinite, we can say of the target audience that there are advertisements for political, economic, religious, or cultural purposes. Economical advertising consists of advertising for political-economic purposes of the state, advertising of enterprises, and advertising of individual enterprise functions, e. g. to increase the sales of goods or services provided by the enterprise (Schweiger \& Schrattenecker 1995: 11). The last two of these cases constitute the focus of the present article.

Advertising reaches its recipients via the media through numerous channels, one of which is print advertisements. The main components of a classic print advertisement include a headline, informative text, slogan, product name, logo, and a graphic image (Janich 2001). The text in an advertisement may be short or long. Short texts have no more than five sentences and have an eye-catching optical character. They have a persuasive rather than informative function and serve to increase the credibility of the advertised product. Long texts in print advertisements, on the other hand, primarily have an informative function and therefore include a more detailed and substantive description of the product or service advertised (Janich 2001: 47).

Language (or languages) play/s a relevant role in advertising, including print advertisements (Sebba 2012). Multilingualism is gradually becoming a large-scale phenomenon in the language of advertising and will presumably continue to grow. In terms of linguistic analysis, multilingual advertisements display the phenomena of code-switching, code-mixing, and borrowing in written speech (Gardner-Chloros 2011: 5-6).

To achieve a greater effect, advertisers often use foreign words or expressions, which in the context of advertising are expected to have a particularly positive influence on the target audience (Kupper 2003: 23-24, Zhiganova 2016: 228). Since English is the most widely learned language in the modern world, as well as the 
language of international communication in many spheres of life, anglicisms are frequently used in advertisements in countries such as Germany, France, or South Korea, even when the target audience of the advertisement is exclusively the local population (Kupper 2003, Zhiganova 2016, Ahn, La Ferle \& Lee 2017). Advertisements that use two or more languages can also target tourists, as shown in a study on Russian-language advertisements in the Chinese border cities of Heihe and Hunchun (Oglezneva, Petrova \& Ying 2016), or the immigrant community, as shown in studies on the use of English and Spanish, or English and Russian in immigrant communities in the US (Angermeyer 2012, Garcia Quintana \& Nichols 2016).

\section{Data and research method}

The present study of advertisements was carried out on print media in the Bavarian city of Nuremberg, which is one of the centres of Russian-speaking immigration. According to Nuremberg city administration's statistics, Russianspeaking immigrants make up $6 \%$ of the city's total population and are one of the largest immigrant communities along with Turkish and Romanian ( $6 \%$ and $4.3 \%$ of the total population, respectively) (Stadt Nürnberg 2011). Consequently, a welldeveloped infrastructure is present in Nuremberg, including several grocery shops with typical post-Soviet food products and a Russian-German cultural centre where German, Bavarian, and local print periodicals for Russian-speaking immigrants are distributed.

The basis of the study is the corpus of 443 advertisements from print media targeted at Russian-speaking immigrants as of September 2019. The advertisements serve as primary sources of information, while the newspapers and magazines, which they are from, serve as metadata, as they provide additional information for the context. All collected advertisements are commercial advertisements. The advertisers in the advertisements are small and medium-sized businesses as well as individuals. The vast majority of the advertisements (437 advertisements, 98.4\%), which are in colour shades, different fonts, and have the main elements of a classic print advertisement, include short texts with a persuasive function. Only six advertisements $(1.6 \%)$ contain long texts with an informative function, as they describe offered products and services in detail.

The specific composition of the target audience for the advertisements studied is not defined. However, the analysis of the products and services offered shows that they target individuals living permanently in Germany but using Russian daily. The content of advertisements offering consular services and travel agency advertisements, e. g. tourist trips from Germany to other countries and airline tickets to various cities in Russia and Kazakhstan, confirm this assumption.

Earlier studies characterize this target group as a "symbolic community of Soviet immigrants" who are, among other things, "united by language" (Goldbach 2005: 24-25). The present study proposes to consider the target audience as a symbolic community of immigrants from the post-Soviet area, for whom Russian 
is a native language, or one regularly used, and serves as a unifying factor for the community. In addition, advertisements show that the target audience is to some extent proficient in German, but perhaps not completely so, as advertisements for legal or medical services, for example, include such expressions as “русскоязычный адвокат" (Russian-speaking lawyer), “русскоязычный персонал" (Russian-speaking staff), or “говорим по-русски" ([we] speak Russian).

The analysis of the material was conducted at two levels: sociolinguistic and linguistic. The quantitative data analysis, followed by an interpretation of the results, aims to draw conclusions at a sociolinguistic level. For this purpose, all advertisements were sorted by subject and language, considering different combinations and the number of languages used. The qualitative data analysis aims to identify language contact phenomena, interpret their use, and compare the results with those from similar studies.

\section{Results}

\subsection{Functions of languages in advertisements}

The first research question deals with the functions that Russian, German, and other languages, if any, have in advertisements printed in the periodicals for Russian-speaking immigrants. Five languages were found in the advertisements: Russian, German, English, Ukrainian, and Latin (see Table 1). However, only three of them - Russian, German, and Ukrainian were used in the advertisements individually, i. e. without combinations with other languages.

Table 1

Distribution of languages in advertisements

\begin{tabular}{|l|l|c|c|}
\hline & language or languages in an advertisement & in figures & as percentage \\
\hline 1 & Russian and German & 345 & 77.9 \\
\hline 2 & Russian & 72 & 16.2 \\
\hline 3 & Russian, German, and English & 10 & 2.3 \\
\hline 4 & German & 9 & 2.0 \\
\hline 5 & Ukrainian & 3 & 0.7 \\
\hline 6 & Russian and English & 2 & 0.5 \\
\hline 7 & Ukrainian and German & 1 & 0.2 \\
\hline 8 & Russian, German, and Latin & 1 & 0.2 \\
\hline & total & 443 & 100 \\
\hline
\end{tabular}

Table 1 gathers all the language combinations found in the advertisements. The table shows that most advertisements are multilingual, primarily in two languages: Russian and German (345 advertisements, 77.9\%). This language combination is understandable in terms of the perceived language knowledge of the target audience, for whom Russian is likely to be the first language and German the second. The second most common combination, using Russian, German, and English, was found in 10 advertisements (2.3\%). In addition, two advertisements use Russian and English, and one each uses Ukrainian and German as well as 
Russian, German, and Latin. The remaining 84 advertisements, representing about $19 \%$ of the total number, were written in one language, which is usually Russian (72 advertisements, $16.2 \%$ ).

\subsubsection{Russian and German and their functions in advertisements}

As described in Section 2.2, a print advertisement can consist of several constituent elements, varying according to the advertiser's objectives. The study shows that the different constituent elements of multilingual advertisements (business or product name, slogans, informative text, service description, contact information, and personal names) include Russian and / or German. Thus, both languages can fulfil different functions.

The Russian language dominates in the elements of advertisements such as headlines, slogans, product, or service names, descriptions, and informative text. In headlines, slogans, and product, or service names, the Russian language performs the functions of attracting attention and introducing, for example, Елена Бекманн ${ }^{l}$ знает, как сделать вати зубы здоровыми, а ульљку неотразимой! (Elena Beckmann knows how to make your teeth healthy and your smile irresistible!), Открывайте мир с нами! (Discover the world with us!), Мы с Вами в дни Вамей скорби. (We are with you in your time of need.), Каждый человек - это Вселенная. (Every person is the universe.), С нами надёжно! (It is safe with us!). As a rule, these elements are highlighted in the advertisements in bright colour, large, or bold type and are immediately apparent. Since the advertisements target the Russian-speaking community, one may assume that advertisers want to attract potential customers or buyers by using a language that is easier to understand. Noteworthy, however, in some advertisements are the names of products, or services that first appear in larger or bolder type in Russian, and then in smaller type, or in brackets in German, е. g. Рьъболовный билет (Angelschein) (Fishing ticket).

Such elements of advertisements as informative texts and descriptions (short listings) of products or services in most multilingual advertisements analyzed are also in Russian. Here, the Russian language performs an informative function, especially in the description of medical, cosmetic, or consular services. The use of Russian may be explained by the desire of advertisers to provide detailed information about their products or services in a way that is as accessible and comprehensible as possible. From this it follows that not all recipients are familiar with the relevant terms in German. The only exceptions are descriptions of legal services which use German terms. In several advertisements, there are services listed in German in bold type, and their explanations in Russian in brackets, e. g. Strafrecht (воровство, наркотики, телесные повреждения и др.) (Criminal law (theft, drugs, bodily injury, etc.)). In these advertisements, Russian and German

${ }^{1}$ All personal names have been changed for the sake of anonymity. 
have reverse functions. The German language has an attention-grabbing function, while the Russian language has a clarifying function.

German includes predominantly such elements of advertisements as company names, logos, and contact details of the advertisers written in Latin characters. The use of German, in this case, is understandable because both advertisers and addressees in the advertisements studied are physically located in Germany. Only in one ad was the name of an elderly care service found, which was taken from the Russian language: Ujut (yюm) (coziness). Thus, the German language performs the informative function here.

However, German has different options in the names of the companies, and the descriptions of the contact details. Along with names like MultiMarkt (literally: multi market), and MixMarkt (literally: mixed market) for shops, or Mill Reisen (Mill travel), Blick Reisen (Blick travel), and Weber Reisedienst (Weber travel service) for travel agencies, advertisements for medical clinics, and lawyers' offices also use both languages. For example, Rechtsanwalt Viktor Schenk / адвокат Виктор Шенк" (lawyer Viktor Schenk) with duplicated information, or межрегиональный урологический Praxis Dr. S. Bondar (interregional urology surgery Dr. S. Bondar) when languages are mixed (see Section 4.3). When describing the contact information, especially in the case of physical addresses of the companies, there are examples where Russian has an explanatory function, e. g. Aвтобус №57 om станции метро Langwasser Mitte (Franken Center) до ост. Moorenbrunn (Bus number 57 from Langwasser Mitte (Franken Center) metro station to Moorenbrunn stop), две минуты пешком от станции метро U3/U6 Münchner Freiheit, вход с улииь Siegfriedstraße, справа от ресторана Мосса (two minutes' walk from U3/U6 Münchner Freiheit metro station, entrance from Siegfriedstraße, right side of Mocca restaurant). The fact that advertisers want to help their potential customers to find the right address quicker, explains the use of Russian here. In addition, several ads also have часы приёма (opening hours), or “часы работы" (business hours) in Russian.

Different options and the use of two languages characterize the spelling of personal names, although all of the advertisers live in Germany and could have written their names exclusively in Latin characters. The first option is the use of the Latin alphabet, for example, for the names of lawyers, doctors, or translators. The second is the use of the Cyrillic alphabet only. This variant was used primarily for personal names of people offering repair and renovation work, non-traditional healing, or spiritual practices, and less frequently for names of lawyers, doctors, and translators. The use of the Cyrillic variant of personal names can be partly explained by the nature of the services provided. In services such as spiritual practices, the use of Cyrillic can work as a positive factor indicating a less formal and more trusting atmosphere when working with clients.

The third option for personal names is the use of both languages. Noteworthy, in some of these cases, is that the names in German and Russian were different, for 
example, Юрий (Yuri) and Jürgen, Иван (Ivan) and Johann, or Лев (Lev) and Leon. Therefore, the use of two languages may be explained by the desire of advertisers to duplicate information to make it easier to find, and, perhaps, by the desire to show that, despite their German names, they are natives of the former Soviet Union and speak Russian. The German first names were probably the result of replacing the Russian names with similar-sounding ones after moving to Germany.

\subsubsection{Ukrainian}

Ukrainian is the subject of four advertisements for immigrants from Ukraine. Three advertisements are entirely in Ukrainian and deal with passenger transport between Germany and Ukraine. The fourth advertisement is in Ukrainian and German and offers translation services. Therefore, the Ukrainian language is used to attract the relevant target audience, which may also speak Russian and use the Russian-speaking infrastructure.

\subsubsection{English}

English, or more precisely, borrowings from English (see Section 4.3) is part of twelve advertisements, in terms like, e. g. online shop, last minute, anti-aging, master of science in oral implantology. The first three examples refer to borrowings from English into German, which can also be found in German advertising texts (Zhiganova 2016: 226). The authors of the advertisements may not know the equivalents of these expressions in Russian, because in several other advertisements were found expressions like горящие путёвки instead of last тіпите, and онлайнмагазин instead of online shop. The fourth example refers to an academic degree, which was probably obtained in an English-speaking country and was, therefore, transferred to the German text without translation.

\subsubsection{Latin}

The use of Latin was recorded only once, in the form of the proverb anima sana in corpore sano (in a healthy body a healthy spirit) in the advertisement of a dentist. In this case, the use of Latin is probably a decoration of the text.

\subsection{Subjects of advertisements and language use}

The second research question asks whether there is a relationship between the subject matter of the advertisements and the language or languages used. Based on the analysis, all advertisements were sorted by subject into 20 groups (see Table 2). The subjects of advertisements cover different areas of life, ranging from legal, consular, medical, and financial services to cultural events, holidays for children, spiritual practices, and funeral services. 
Breakdown of advertisements by subject

\begin{tabular}{|c|l|c|c|}
\hline \multicolumn{1}{|c|}{ subject } & in figures & as percentage \\
\hline 1 & tourism and transport & 92 & 20.8 \\
\hline 2 & medicine & 75 & 16.9 \\
\hline 3 & legal services & 40 & 9 \\
\hline 4 & goods & 35 & 7.9 \\
\hline 5 & translation services & 24 & 5.4 \\
\hline 6 & beauty salons & 23 & 5.2 \\
\hline 7 & funeral services & 21 & 4.7 \\
\hline 8 & cars & 16 & 3.6 \\
\hline 9 & grocery shops & 15 & 3.4 \\
\hline 10 & consular services & 14 & 3.2 \\
\hline 11 & spiritual practices & 14 & 3.2 \\
\hline 12 & media & 14 & 3.2 \\
\hline 13 & restaurants & 12 & 2.7 \\
\hline 14 & finance and credit & 10 & 2.2 \\
\hline 15 & cultural events & 8 & 1.8 \\
\hline 16 & job advertisements & 8 & 1.8 \\
\hline 17 & repair and finishing work & 6 & 1.4 \\
\hline 18 & courses and events for children & 4 & 0.9 \\
\hline 19 & marriage in Denmark & 4 & 0.9 \\
\hline 20 & diverse & 8 & 1.8 \\
\hline & total & 443 & 100 \\
\hline
\end{tabular}

The two most numerous groups of advertisements are tourism and transport, and medicine. Thus, these groups and their thematic relationship with language use will be treated separately.

The biggest number of advertisements $(20.8 \%)$ belongs to the group tourism and transport, represented by travel agencies and companies providing diverse forms of passenger transport. It follows from the advertisements that these companies specialize in Russian-speaking customers because they offer airline tickets and tourist trips to the former Soviet Union countries, as well as visas and postal services. The presence of many advertisements in this group is, on the one hand, due to the size of the Russian-speaking community in Germany and, on the other, to the relative geographical distance of Russian-speaking immigrants from countries like Kazakhstan, Kyrgyzstan, or parts of Russia from which they emigrated.

All advertisements in this group are multilingual with either German and Russian, or German and Ukrainian. However, Russian predominates, as headlines, slogans, short informative texts, and listings of services are mostly written in Russian. The predominance of Russian may be explained by the geographical specialization of the advertisers' products. German appears in all advertisements to convey the contact details of companies and, in some cases, in geographical names, e. g. Meersburg. Furthermore, in several advertisements, words or phrases in German were found in bold or in red, as in German travel advertisements, e. g. 
Frühbucherrabatt (early bird rebate), VIP-Klasse (vip class), Neu (new), Jetzt buchen (book now).

The second-largest group of advertisements (16.9\%) relates to medicine. This group consists of advertisements for private doctors' surgeries and clinics, mainly dental clinics, where either the doctors themselves are from the former Soviet Union, or some of the staff speak Russian. This group also includes care services for the sick and elderly. The large number of advertisements in the medical field are explained by the fact that medical vocabulary is too specific and unfamiliar to most immigrants. Therefore, doctors or nursing staff who speak the patients' native language and understand them better have a clear advantage over doctors who do not speak Russian.

The advertisements from the group medicine contain both languages. The list of services and slogans is usually written in Russian. Only a few advertisements include the same short, informative text in both languages. In addition to contact information, some advertisements also include qualifications of doctors in German, e. g. Dr. med. dent., Facharzt für Allgemeinmedizin (general practitioner), Professor (professor), or the specialization of the doctor's office, e. g. Kieferorthopädie (orthodontics). As mentioned earlier, most Russian-speaking immigrants are not familiar with the medical vocabulary in German. However, there are no advertisements in Russian only in this group.

The advertisements on other subjects were divided into three groups depending on the languages or language combinations. In the first (and most numerous) group are ads where Russian is the predominant language. These include advertisements for goods, consular services, spiritual practices, restaurants, cultural events, beauty salons, job advertisements, and courses and events for children. However, within the group, there are significant differences between the advertisements for the particular subjects. For example, the group of advertisements labelled spiritual practices includes fortune-tellers, healers, psychics, and sorcerers, how they call themselves, and also advertisements for Christian churches. Half of the advertisements on this subject contain a telephone number, without an address, and use only Russian. The advertisements for restaurants and beauty salons use German only for contact information. This may be explained by the fact that advertisers want to emphasize the specifics of their services exclusively for Russian-speaking customers. The situation is different in the goods advertisements. Most of them use Russian to refer to certain products, and German only in the case of a specific model of a product.

The second group includes advertisements for media, marriage in Denmark, and repair and finishing work, where absolutely all advertisements are in Russian. These advertisements contain only telephone numbers (repair and finishing work, marriage in Denmark) or website addresses (marriage in Denmark, media). In this case, it is possible that the advertisers deliberately chose Russian, because they do not expect their potential customers to have sufficient knowledge of German. 
The third group includes advertisements for legal services, translation services, cars, finance and credit, and grocery shops using both languages, but without the predominance of Russian. In this group, there are advertisements where the entire information is given in both Russian and German (translation services), where German is predominant (legal services), or where the advertisements are entirely in German (finance and credit, translation services, cars, legal services). The more frequent use of German, specifically in advertisements on these subjects, may be a result of the pragmatical thinking of advertisers. Despite specializing in Russian-speaking clients, they still want to attract non-Russian-speaking customers as well. For example, grocery shops offer Polish products and use German in their advertisements to reach Polish immigrants in Germany who visit these shops. The use of German may also result from the desire of advertisers to save advertising costs and print only one version of the ad in different print media, e. g. in the case of law offices or companies selling car parts. It is noteworthy, however, that no subject group consists entirely of advertisements written in German only.

\subsection{Language contact phenomena in advertisements}

The third research question focus on the language contact phenomena specific to advertisements. Earlier studies show that language contact phenomena in the immigrant speech primarily appear at the lexical and prosodic levels (Riehl 2009, Matras 2011, Warditz 2019). After a longer period of contact between two languages, these phenomena emerge at the levels of morphology and syntax. However, there are exceptions when language contact phenomena are present at different language levels after a brief contact between two languages (Weinreich 1967, Warditz 2019). The analysis carried out in this study found language contact phenomena at the lexical and morphosyntactic levels. Most of them are the result of the contact between German and Russian. A few cases of contact between German, Russian, and English are part of the present study.

\subsubsection{Lexical level}

\section{a) Borrowings without an equivalent in Russian}

As in the spoken language of Russian-speaking immigrants, print advertisements contain concepts and phenomena, which are either specific to Germany, or have no exact translation into Russian. One example is the German word Praxis (surgery) and its derivatives Arztpraxis, Zahnarztpraxis (doctor's surgery, dental surgery), which may be translated into Russian as 'частный врачебный кабинет' (private doctor's office), 'кабинет врача' (doctor's office), or even 'частная медицинская клиника' (private medical clinic) (cf. Goldbach 2005: 53).

Four options for this word were found in the advertisements studied. First option: German term written in Latin characters, e. g. Zahnarztpraxis (dental surgery). Second option: a mixture of languages and alphabets, e. g. стоматологический Praxis (dental surgery). In this option, the word 'Praxis,' 
which in German is feminine gender, is borrowed into Russian, and according to the rules of determining the gender in Russian, becomes masculine. Hence, the adjective 'стоматологический' also becomes masculine. The third option differs from the second only in the sense that both words are written in Cyrillic characters, e. g. физиотерапевтический праксис (physiotherapeutic surgery).

Fourth option: the use of the word 'праксис' in the masculine gender as an independent member of a sentence in Russian, е. g. Наш праксис переехал. (Our surgery has moved.), or Праксис расположен в 150 метрах от станции метро. (The surgery is located 150 meters from the metro station.). Furthermore, several advertisements contain variants with vocabulary of similar meaning used instead of the word 'Praxis.' Some advertisers replaced it with a Russian word 'практика' (practice), е. g. стоматологическая практика (literally: dental practice). Other advertisements contain the following terms: частный ортопедический институт (literally: private orthopedic institute), and урологическая клиника (urological clinic). Some advertisements do not mention the name of the organization at all, but use the doctor's specialization, е. g. врач ухо-горло-нос (literally: ear, nose and throat doctor), or врач-кардиолог (cardiologist).

Another German word that is characteristic of everyday life in Germany and has no equivalent in Russian (cf. Pabst 2007: 69 and 75) is 'Termin' (appointment). Depending on the specific situation and context, this word may be translated into Russian as 'приём' (appointment), e. g. with a doctor, 'консультация' (consultation), e.g. with a lawyer or a doctor, 'встреча, назначенная на определённое время' (meeting set for a certain time), 'назначенный срок' (appointed time), or 'назначенная дата' (fixed date). In the spoken language of Russian-speaking immigrants in Germany, the word 'Termin' is used quite often (Goldbach 2005: 54, Pabst 2007: 69).

In the present study, the use of this word was recorded in written language, e. g. Позаботьтесь о термине по телефону (Arrange an appointment by phone), or термины по договорённости (appointments by arrangement). In both examples, the German word 'Termin' was integrated morphologically (case endings and plural endings), and graphically (written in Cyrillic characters with a lowercase initial letter). In addition, several medical advertisements contain such translations as запись на консультаиию (making of an appointment), and Запишитесь на приём (Make an appointment).

Furthermore, the German word 'Amt' (department), found in two medical advertisements, is often used in the spoken language in a Russian-speaking immigrant environment (Goldbach 2005, Pabst 2007). This word was also integrated morphologically into Russian and received the masculine gender as well as the plural ending according to the rules of the Russian language: сопровождение в амты (escorting to departments), and сопровождаем в амты ([we] escort to departments).

In travel advertisements, the most frequent case was the German term 'Pauschalreise' (package tour), which may be translated into Russian as 'тур' 
(tour), 'пакетный тур' (package tour), or 'комплексная туристическая поездка' (all-inclusive tourist trip). Some advertisements use the German term 'Pauschalreise' without integration into the Russian language. Other advertisements use Russian words with similar meaning like 'поездки' (trips), or 'экскурсии' (excursions). Finally, in some advertisements, the result of language mixing is a hybrid term 'паушальные поездки' (package tour (German) + trips (Russian)). This hybrid term may be seen as a kind of attempt at creative translation (McStay 2013).

\section{b) Borrowings with equivalents in Russian}

This group of borrowings from the German language includes words that have a semantically close equivalent in the Russian language, but nevertheless are used in advertisements in German and written in Latin or Cyrillic characters. Several advertisements use the word 'Parkplatz' (parking), written in Latin characters and added to Russian without any morphological change, e. g. Parkplatz во дворе (Parking in the yard), or Parkplatz в любом аэропорту Германии (Parking at any German airport). Other examples of German words written in Latin characters and partially integrated into Russian were found in job advertisements such as вакансия на Vollzeit / Teilzeit (vacancy for a full / part-time job), ежегодный Weiterbildung (annual advanced training), and in travel advertisements such as поездки на Weihnachten (trips at Christmas time), and Черногория, Беларусь NEU (Montenegro, Belarus NEW).

In addition to borrowings from German into Russian, this category includes examples of borrowings from English. Most likely English expressions were first borrowed from English into German, as they are present in advertisements of German travel agencies, and later appeared in advertisements for Russian-speaking immigrants. A typical example is the term 'Last minute' or 'Lastminute' taken from English and written in advertisements according to German spelling rules as a noun with a capital letter. Despite the Russian equivalent of 'горящая путёвка' (literally: burning ticket), the English version with the German spelling was found in five advertisements, while the Russian version was found only in one. The use of the English version may be partly explained by the lack of knowledge of the Russian version among immigrants. A similar example from travel-related advertisements is the word 'online,' е. g. 'online бронирование,' or 'online-бронирование' (online booking) used in many advertisements. The Russian version ‘бронирование в интернете' (online booking) was found only once.

\subsubsection{Morphosyntactic level}

Because of the structure of print advertisements, they do not usually contain linguistic constructions that could be labelled as sentences according to the rules of the Russian or German language. This fact was one of the reasons why far fewer language contact phenomena were found on the morphosyntactic level than on the lexical level. The examples found were divided into two groups. 
One group includes examples with several single borrowings, often written in Latin characters. A typical example is the following sentence taken from an advertisement of a curtain shop: Заказы принимаются по Телефону, по E-Mail, а также на нашем Hотераge. (Orders can be placed by telephone, via e-mail, or on our homepage.). Here, there is obviously a significant influence of the German language on Russian. First, the words 'E-Mail' and 'Homepage,' although originally borrowed from English, are written in German, i. e. with a capital letter like all German nouns, and in Latin characters. Noteworthy is the word 'Homepage,' which in English has no gender and in German is feminine: in this sentence it appears with the pronoun 'our' and can be either masculine or neuter. Secondly, the word for telephone is written in Russian, but according to the rules of the German language, starts with a capital letter. A similar example was found in an ad of a travel company offering trips to health resorts with various treatment courses: Помощь в заполнении ANTRAG на курорт и получении оплаты от Krankenkasse! (Help in filling in the application for the spa and receiving payment from a health insurance company!). In another travel ad, borrowings from both German and English were found: Незабываемый отдых на море; лучиие курорты мира; Frühbucherrabatt; Griechenland; оплата в кредит; отели доступные, VIP-Klasse; Last Minute скидка до 65\%; все туроператоры; Spanien; Туриия; компетентность, опыт, знания, уважение к клиентам. (Unforgettable holiday at sea; best resorts of the world; early bird rebate; Greece; credit payment; hotels available, VIP-class; last-minute discount up to 65\%; all tour operators; Spain; Turkey; competence, experience, knowledge, respect for clients.). Although in the first two examples the borrowings are only partially integrated morphologically, they fit into the sentence structure in terms of syntax. It is noteworthy, however, that all the three examples give a visual impression of language mixing, because of the use of several words written in Latin characters.

The second group contains cases not only with single German or English words, but with phrases and sentences. A typical example of this group is a short text from a travel advertisement: Надёжно, качественно, быстро, недорого! Gut reisen mit GuT Reisen. Дешевле просто не бывает! (Reliable, high quality, fast, cheap! Good trip with GuT Reisen. You cannot get any cheaper than that!). This text consists of three sentences written in one line, separated by punctuation marks. The first and third sentences are in Russian, the second in German. Thus, this text contains the phenomenon of code-switching from Russian to German and back.

Similar cases of code-switching were found in other advertisements in the subject groups tourism and transport, job advertisements, and finance and credit. Two of the examples are short texts: Новая служба nо уходу Vita Pflegedienst приглашает к сотрудничеству специалистов: Krankenschwester / Krankenpfleger, Gesundheits- und Krankenpfleger/in, Altenpfleger/in, Betreuungskräfte. Onыт работы в подобных службах приветствуется. (New care service Vita Pflegedienst welcomes applications: female nurse / male nurse, nurse for the elderly, supporting personnel. Experience in similar services is 
welcomed.), and Требуются на постоянное трудоустройство (für den Standort in 21224 Rosengarten) LKW Fahrer, Kommissionierer. Bewerbung высылать на E-Mail: ... (Truck driver and order picker are needed for permanent employment (for the location in 21224 Rosengarten). Letter of application on e-mail: ...).

In the two other examples, the switch from Russian to German occurs within the sentence: Лemo 2020, XXL Rabatt do 44\% (Summer 2020, XXL discount up to 44\%), and Передача \% от третьих лии; подтверждение \% от всех страховых фирм; страхование груза Transportversicherung; Kurierdienst, Pflegedienst - c 30\%; LKW Transporte, Taxi, Reisebus. (Transfer of \% from third parties; confirmation of $\%$ from all insurance companies; cargo insurance; transport insurance; courier service, nursing service - with $30 \%$; truck transports, taxi, touring coach.). The results of the analysis cited are comparable to the results of research on the phenomenon of code-switching in oral speech, where in one utterance the speaker switches from one language to another, e. g. in the case of indirect speech, and then returns to the first language (Riehl 2009: 24, Gardner-Chloros 2011: 104-105).

\subsubsection{Spelling}

In addition to language contact phenomena, spelling errors were repeatedly found in the advertisements studied. For example, in a psychologist's advertisement the word 'дипрессия,' instead of 'депрессия' (depression) was written. An advertisement of a private medical surgery gives information on diseases of the 'опорнодвигательный аппарат', instead of 'опорно-двигательный аппарат' (musculoskeletal system). Finally, in one other advertisement: 'частное охранное агенство', and not 'частное охранное агентство' (private security agency) offers its services. These mistakes may be a result of inattention, or they could be printing errors. But an alternative explanation is also possible. Since neither the advertisers, nor the editors of the newspapers, where the advertisements were printed, paid attention to the spelling of these words, it is also possible that they had forgotten or did not know the correct spelling.

\section{Conclusions}

The results of the analysis show that the situation of language contact, as described in earlier studies on the spoken language of Russian-speaking immigrants in Germany, is partly reflected in the written language in advertisements. Despite the lengthy stay of most of the described target group in Germany, Russian nevertheless fulfils numerous functions in most multilingual advertisements and determines the grammatical and graphical structure of the advertisements. Besides, the majority of monolingual advertisements are in Russian. Thus, at least for the Russian-speaking community in Nuremberg, Russian continues to play an important role in communication, is one of the unifying factors, and a component of identity. Links between language choice in advertisements, target group behavior, and ethnic identity in immigrant communities were also found in other 
similar studies (Sebba 2012, Angermeyer 2012: 261, Garcia Quintana \& Nichols 2016: 236).

The results of this study coincide with the results of the studies on the spoken language of Russian-speaking immigrants, which also emphasize that Russian, although gradually losing its position, nevertheless continues to be one of the languages used at home and within the community. Furthermore, it has its value as a specific potential and resource for immigrants (Ritter 2018: 248, Meng 2019: 129-133, Soultanian 2019: 412, Warditz 2019: 283, Dietz \& Roll 2019: 109).

German is the second most important language used for some elements of the advertisements, or even for the whole advertisements, competing with Russian. Therefore, it is possible that the role of German in advertisements will continue to grow in the future, as similar studies on spoken language show (Ritter 2018: 248, Meng 2019: 133). This is primarily due to the fact that the second generation of Russian-speaking immigrants, already born in Germany, cannot as a rule read and write in Russian, and do not learn this language at school, which leads to a progressive decline in language level (Dietz \& Roll 2019: 110-111).

The subject variety of advertisements (from medicine and lawyers to spiritual practices, from job advertisements to invitations to Russian-speaking cultural events), using Nuremberg as an example, confirms the high level of development of the Russian-speaking infrastructure in Germany. On the one hand, this means that Russian-speaking immigrants are at least able to do without the German language in some spheres of life. On the other hand, Russian-speaking immigrants working, for example, in law offices, medical clinics, grocery shops, cultural centres, or in the editorial offices of Russian newspapers, are part of the Russianspeaking infrastructure and have the opportunity to use Russian in the workplace regularly. This fact also confirms the heterogeneity of the Russian-speaking community in terms of social status. The differences in the use of Russian, German, and, in some cases, Ukrainian in advertisements on certain subjects are closely related to the preferences and goals of advertisers, and to the subjects of the advertisements.

The study revealed phenomena of contact between Russian, German, and English at the lexical and morphosyntactic level in written language. These data are partly comparable to the results obtained from the analysis of the spoken language of Russian-speaking immigrants in Germany. German is the main source of borrowings in Russian, whether due to ignorance of Russian equivalents or due to lack of them. Therefore, several studies on the spoken language (Goldbach 2005, Pabst 2007, Pavlova 2019) and the present study on the written language have identified the fact that some words are borrowed from German into Russian more often than others. The results of the analysis of language contact on the morphosyntactic level are partly comparable to the results of Warditz (2019: 298), who derived general trends of the Russian language change on the morphosyntactic level among Russian-speaking immigrants in Germany. 
However, by contrast with the spoken language, the language contact phenomena in advertisements are not considered in the context of a single sentence or an utterance, but in the context of a single advertisement. Furthermore, they depend on its graphical arrangement and its use in a certain element of the advertisement (cf. Zhiganova 2016: 228, Oglezneva, Petrova \& Ying 2016: 196). The code-switching phenomena found in the studied advertisements also have their peculiarities in contrast to the spoken language. First, their frequency of use is directly related to the limited number of language constructions used in advertisements. Second, they fulfil specific functions in the structure of the advertisements, i. e. their use is not random. Finally, one more relevant feature of multilingualism in written advertisements is the purposeful use of two alphabets (Angermeyer 2012), e. g. to draw attention to a particular piece of information, or the intentional avoidance of Latin script, e. g. when German borrowings are integrated into Russian-language constructions or are absent.

In conclusion, it is noteworthy to add that the study of print advertisements for Russian-speaking immigrants highlights one aspect of the linguistic situation of this immigrant community in Germany as a whole. The results of the present study may serve to complement the findings of other studies in this field since the present study was conducted on a relatively numerous Russian-speaking community of the city of Nuremberg. Furthermore, the results of this study may implicitly serve to assess the vitality of the Russian language in Germany (cf. Achterberg 2005). As the linguistic situation of an immigrant community is dynamic, a follow-up study may be carried out in a few years to identify possible changes in the use and functions of languages.

(C) Anna Ritter, 2021 @creative

This work is licensed under a Creative Commons Attribution 4.0 International License https://creativecommons.org/licenses/by/4.0/

\section{REFERENCES}

Achterberg, Jörn. 2005. Zur Vitalität Slavischer Idiome in Deutschland. Eine Empirische Studie zum Sprachverhalten Slavophoner Immigranten. München: Verlag Otto Sagner.

Ahn, Jungsun, Carrie La Ferle \& Doohwang Lee. 2017. Language and advertising effectiveness: Code-switching in the Korean marketplace. International Journal of Advertising 36 (3). 477-495.

Angermeyer, Philipp S. 2012. Bilingual meets digraphia: Script alternation and hybridity in Russian-American writing and beyond. In Mark Sebba, Shahrzad Mahootian \& Carla Jonsson (eds.), Language Mixing and Code-Switching in Writing. Approaches to MixedLanguage Written Discourse, 255-272. London/New York: Routledge.

Armstrong, Scott J. 2010. Persuasive Advertising. Evidence-Based Principles. Basingstoke: Palgrave Macmillan. 
Arslanagic-Kalajdzic Maja \& Vesna Zabkar. 2016. Understanding agency-client relationships better through clients' perceptions of value and value antecedents. In Peeter Verlegh, Hilde Voorveld \& Martin Eisend (eds.), Advances in Advertising Research (Vol. VI). The Digital, the Classic, the Subtle, and the Alternative, 101-114. Wiesbaden: Springer Gabler.

Baur, Rupprecht S., Christoph Chlosta \& Heike Roll. 2019. Zur Geschichte der Russlanddeutschen. In Kai Witzlack-Makarevich \& Nadja Wulff (eds.), Handbuch des Russischen in Deutschland. Migration - Mehrsprachigkeit - Spracherwerb, 81-100. Berlin: Frank \& Timme.

Dietz, Barbara \& Heike Roll. 2019. Die Einwanderung aus der Sowjetunion und ihren Nachfolgestaaten. In Kai Witzlack-Makarevich \& Nadja Wulff (eds.), Handbuch des Russischen in Deutschland. Migration - Mehrsprachigkeit - Spracherwerb, 101-114. Berlin: Frank \& Timme.

Garcia Quintana, Ashley E. \& Cynthia A. Nichols. 2016. Code switching and the Hispanic consumer: The effects of acculturation on the language of advertising among Hispanics. Hispanic Journal of Behavioral Sciences 38 (2). 222-242.

Gardner-Chloros, Penelope. 2011. Code-Switching. Cambridge: Cambridge University Press. Gogolin, Ingrid. 1998. Sprachen rein halten - eine Obsession. In Ingrid Gogolin, Sabine Graap \& Günther List (eds.), Über Mehrsprachigkeit, 71-96. Tübingen: Stauffenburg.

Goldbach, Alexandra. 2005. Deutsch-Russischer Sprachkontakt. Deutsche Transferenzen und Code-Switching in der Rede Russischsprachiger in Berlin. Frankfurt am Main: Peter Lang.

Haug, Sonja \& Lenore Sauer. 2007. Zuwanderung und Integration von (Spät-)Aussiedlern. Ermittlung und Bewertung der Auswirkungen des Wohnortzuweisungsgesetzes. Forschungsbericht 3. Nürnberg: Bundesamt für Migration und Flüchtlinge.

Haugen, Einar. 1956. Bilingualism in the Americas: A Bibliography and Research Guide. Alabama: University of Alabama Press.

Janich, Nina. 2001. Werbesprache. Ein Arbeitsbuch. Tübingen: Narr.

Kharitonova-Akhvlediani, Anastasia. 2011. Russischsprachige Printmedien und Integration. Berlin: Universitätsverlag der TU Berlin. https://depositonce.tu-berlin.de/bitstream/ 11303/3144/1/Dokument_8.pdf(accessed 18 May 2021).

Kupper, Sabine. 2003. Anglizismen in deutschen und französischen Werbeanzeigen. Zum Umgang von Deutschen und Franzosen mit Anglizismen. Marburg: Tectum.

Matras, Yaron. 2011. Language Contact. Cambridge: Cambridge University Press.

McStay, Andrew. 2013. Creativity and Advertising. Affect, Events and Process. London/New York: Routledge.

Meng, Katharina. 2019. Russlanddeutsche Sprachentwicklungen im "Zeitalter der Extreme": Familien- und generationsbezogene Sprachbiografien. In Kai Witzlack-Makarevich \& Nadja Wulff (eds.), Handbuch des Russischen in Deutschland. Migration Mehrsprachigkeit - Spracherwerb, 115-136. Berlin: Frank \& Timme.

Muysken, Pieter. 2000. Bilingual Speech. A Typology of Code-Mixing. Cambridge: Cambridge University Press.

Oglezneva, Elena, Tatyana Petrova \& Jiang Ying. 2016. Features of language communication in a multicultural community: Russian texts of advertising signboards in the border cities of China. Procedia - Social and Behavioral Sciences 236 (2016). 194-200.

Pabst, Birte. 2007. Russisch-Deutsche Zweisprachigkeit als Phänomen der Multikulturellen Gesellschaft in Deutschland. Frankfurt am Main: Peter Lang.

Pavlova, Anna. 2019. Sprachliche Normbrüche russischer EmigrantInnen der zweiten Generation in Deutschland im Vergleich mit sprachlichen Trends im heutigen Russland. In Kai Witzlack-Makarevich \& Nadja Wulff (eds.), Handbuch des Russischen in 
Deutschland. Migration - Mehrsprachigkeit-Spracherwerb, 323-344. Berlin: Frank \& Timme.

Riehl, Claudia M. 2009. Sprachkontaktforschung. Eine Einführung. Tübingen: Narr.

Ritter, Anna. 2018. To what extent are different languages spoken in an immigrant family?

A case study of Russian-German families in Germany. In Elena Babatsouli (ed.), Crosslinguistic Research in Monolingual and Bilingual Speech, 236-252. Chania, Greece: ISMBS.

Roche, Jörg. 2001. Interkulturelle Sprachdidaktik. Eine Einführung. Tübingen: Narr.

Rogge, Hans-Jürgen. 2000. Werbung. Ludwigshafen: Kiehl.

Schweiger, Günter \& Gertraud Schrattenecker. 1995. Werbung. Frankfurt am Main: Fischer.

Stadt Nürnberg. 2011. Menschen mit Migrationshintergrund in Nürnberg. Nürnberg:

W. Tümmels Buchdruckerei und Verlag. https://www.nuernberg.de/imperia/md/statistik/ dokumente/migration/datenblatt/2010/migrationshintergrund_n1_2011.pdf (accessed 18 May 2021).

Sebba, Mark. 2012. Researching and Theorising Multilingual Texts. In Mark Sebba, Shahrzad Mahootian \& Carla Jonsson (eds.), Language Mixing and Code-Switching in Writing. Approaches to Mixed-Language Written Discourse, 255-272. London/New York: Routledge.

Statistisches Bundesamt. 2019. Bevölkerung in Privathaushalten nach Migrationshintergrund im weiteren Sinn nach ausgewählten Geburtsstaaten. https://www.destatis.de/DE/ Themen/Gesellschaft-Umwelt/Bevoelkerung/Migration-Integration/Tabellen/ migrationshintergrund-staatsangehoerigkeit-staaten.html (accessed 18 May 2021).

Statistisches Bundesamt. 2019. Bevölkerung in Privathaushalten nach Migrationshintergrund im weiteren Sinn nach Geburtsstaat in Staatengruppen. https://www.destatis.de/DE/ Themen/Gesellschaft-Umwelt/Bevoelkerung/Migration-Integration/Tabellen/ migrationshintergrund-staatsangehoerigkeit-staatengruppen.html (accessed 18 May 2021).

Stavans, Anat \& Charlotte Hoffmann. 2015. Multilingualism. Cambridge: Cambridge University Press.

Swann, Joan, Ana Deumert, Theresa Lillis \& Rajend Mesthrie. 2004. A Dictionary of Sociolinguistics. Tuscaloosa: The University of Alabama Press.

Velupillai, Viveka. 2012. An Introduction to Linguistic Typology. Amsterdam: John Benjamins Publishing Company.

Warditz, Vladislava. 2019. Russisch als Migrationssprache in Deutschland: Zur Typologie des Mikrosprachwandels (Eine systemlinguistische Studie). In Kai Witzlack-Makarevich \& Nadja Wulff (eds.), Handbuch des Russischen in Deutschland. Migration Mehrsprachigkeit - Spracherwerb, 283-302. Berlin: Frank \& Timme.

Weinreich, Uriel. 1967. Languages in Contact, Findings and Problems. London: Mouton de Gruyter.

Worbs, Susanne, Eva Bund, Martin Kohls \& Christian Babka von Gostomski. 2013. (Spät-)aussiedler in Deutschland. Eine Analyse Aktueller Daten und Forschungsergebnisse. Nürnberg: Bundesamt für Migration und Flüchtlinge. https://www.bamf.de/SharedDocs/Anlagen/DE/Forschung/Forschungsberichte/ fb20-spaetaussiedler.pdf?_blob=publicationFile \&v=14 (accessed 18 May 2021).

Zhiganova, Anna V. 2016. The study of the perception of code-switching to English in German advertising. Procedia - Social and Behavioral Sciences 236 (2016). 225-229.

\section{Article history:}

Received: 15 May 2021

Accepted: 19 October 2021 


\section{Bionote:}

Anna RITTER is a Research Associate at the University of Regensburg (Germany). Her research interests include sociolinguistics, code-switching, family language policy, and German as a second language. She has articles published in Critical Multilingualism Studies (an interdisciplinary journal) and Zeitschrift für Interkulturellen Fremdsprachenunterricht.

\section{Contact information:}

Universität Regensburg

Universitätsstraße 31, VG 3.27

93053 Regensburg

e-mail: anna.ritter@ur.de

ORCID: 0000-0001-6790-5531

\section{Сведения об авторе:}

Анна РИТТЕР является научным сотрудником Регенсбургского университета (Германия). Область ее научных интересов - социолингвистика, переключение кодов, семейная языковая политика и немецкий как второй язык. Ее публикации включают статьи в журналах Critical Multilingualism Studies и Zeitschrift für Interkulturellen Fremdsprachenunterricht.

\section{Контактная информация:}

Universität Regensburg

Universitätsstraße 31, VG 3.27

93053 Regensburg

e-mail: anna.ritter@ur.de

ORCID: 0000-0001-6790-5531 